\title{
PENGARUH PEMBERIAN EKSTRAK ETANOL KAYU SECANG (Caesalpinia sappan L.) SECARA SUBKRONIK TERHADAP BOBOT JANTUNG DAN PARU TIKUS PUTIH JANTAN (Rattus norvegicus)
}

\author{
Rezaldi Mahaputra Perdana, Muhammad Nur Amir, Sukamto S Mamada \\ Fakultas Farmasi, Universitas Hasanuddin, Makassar, Indonesia
}

Kata Kunci :

Kayu secang

(Caesalpinia sappan L.), tikus putih jantan

(Rattus norvegicus), subkronik, toksisitas, jantung, paru-paru $\begin{array}{ll}\text { Masuk } & 14-07-2020 \\ \text { Revisi } & 07-08-2020 \\ \text { Diterima } & 20-008-2020\end{array}$

DOI: 10.20956/mff.v24i2.10683

Korespondensi

Muhammad Nur Amir

nuramir@unhas.ac.id

Copyright

(C) 2020 Majalah Farmasi

Farmakologi Fakultas Farmasi

Makassar

Diterbitkan tangga

20 Agustus 2020

Dapat Diakses Daring Pada: http://journal.unhas.ac.id/index.php/mff

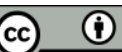

\section{ABSTRAK}

Kayu secang merupakan salah satu tanaman yang sering digunakan untuk terapi pengobatan, sehingga perlu dilakukan pengujian untuk mengetahui keamanan dari tanaman tersebut. Telah dilakukan penelitian mengenai pengaruh pemberian ekstrak etanol kayu secang (Caesalpinia sappan L.) secara subkronik terhadap bobot jantung dan paru tikus putih jantan (Rattus norvegicus). Tujuan penelitian ini adalah untuk mengetahui efek toksisitas ekstrak etanol kayu secang (Caesalpinia sappan L.) berdasarkan parameter bobot jantung dan paru-paru tikus putih jantan (Rattus norvegicus) setelah pemaparan subkronik selama 90 hari. Dua puluh ekor tikus putih dibagi menjadi 4 kelompok perlakuan yaitu kelompok 1 kontrol sehat, kelompok 2 NaCMC 1\%, kelompok 3 ekstrak etanol kayu secang 400 mg/kg BB, dan kelompok 4 ekstrak etanol kayu secang $1000 \mathrm{mg} / \mathrm{kg}$ BB. Perlakuan dilakukan selama 90 hari dengan aturan pemberian 1 kali sehari. Efek toksisitas ditentukan melalui pengukuran bobot jantung dan paru-paru. Hasil yang diperoleh menunjukkan bahwa pemberian ekstrak etanol kayu secang secara subkronik selama 90 hari tidak menyebabkan toksisitas berdasarkan data bobot jantung dan paru-paru tikus putih jantan yang diperoleh.

\section{PENDAHULUAN}

Pengobatan tradisional telah dilakukan sejak dahulu secara turun temurun oleh masyarakat Indonesia. Di Indonesia sendiri terdapat sekitar 30.000 jenis tanaman dan 7.000 diantaranya memiliki khasiat sebagai obat (1). Meskipun pengobatan modern telah berkembang hingga ke pelosok daerah, tetapi penggunaan tanaman sebagai obat masih tetap diminati. Tanaman obat semakin intensif untuk dipelajari, bukan hanya karena tradisi, tetapi terutama nilainya di bidang farmasi (2).

Berdasarkan data World Health Organization (WHO), 60-80\% dari populasi di beberapa negara masih bergantung dari pengobatan tradisional sebagai pilihan pengobatan utama masyarakatnya, termasuk negara-negara di Asia Tenggara. World Health Organization (WHO) bahkan memprediksi permintaan tanaman obat mencapai nilai USD 5 triliun pada tahun 2050 (3).

Salah satu tanaman yang sering digunakan sebagai terapi pengobatan adalah secang (Caesalpinia sappan L.). Kayu secang diketahui memiliki banyak khasiat penyembuhan dan sering dikonsumsi oleh masyarakat sebagai minuman kesehatan. Kandungan kimia yang terdapat pada tanaman secang antara lain alkaloid, asam galat, brazilein, brazilin, flavonoid, minyak atsiri, oscimene, resin, resorsin, saponin, dan tanin (4).

Penelitian menunjukkan bahwa konsentrasi 400 $\mu \mathrm{g} / \mathrm{ml}$ ekstrak metanol kayu secang (Caesalpinia sappan L.) yang diteteskan pada kedua mata tikus putih menghasilkan efek antiangiogenesis pada tikus putih (Rattus norvegicus) (5). Studi lain pada hewan coba tikus putih mengonfirmasi bahwa ekstrak etanol C. sappan memiliki efek hipo- lipidemik (6). Adapun penelitian yang dilakukan Pertamawati, dkk (2017) menunjukkan bahwa ekstrak etanol C. sappan dengan dosis $125 \mathrm{mg} / 200$ g BB mampu memberikan efek diuretik pada tikus putih. Aktivitas antioksidan tanaman ini dilaporkan sangat kuat dengan nilai $\mathrm{IC}_{50}=15,69$ ppm (8). Penelitian lain melaporkan aktivitas antioksidan kayu secang (Caesalpinia sappan L.) yang dilakukan oleh Rusdi, dkk (2005) menunjukkan efek antioksidan paling baik dibanding vitamin $\mathrm{C}$ dan $\mathrm{E}$, serta mampu meningkatkan nilai SAT (Status Antioksidan Total) dari $2,39 \mathrm{mmol} / \mathrm{L}$ menjadi 4,38-7,58 $\mathrm{mmol} / \mathrm{L}$.

Laporan berbagai efek farmakologi kayu secang (Caesalpinia sappan L.) di atas harus diikuti oleh studi-studi lanjutan untuk mengonfirmasi efek toksikologi yang berpotensi dimiliki tanaman uji ini. Uji toksikologi terhadap berbagai sistem tubuh harus dilakukan untuk melengkapi safety data tanaman ini.

Jantung merupakan organ vital di dalam tubuh yang terdiri dari otot-otot kuat, berfungsi untuk memompa darah, membawa oksigen, serta membawa makanan melalui pembuluh darah menuju ke seluruh jaringan tubuh (10). Ukuran jantung normal manusia besarnya segenggam tangan kiri pemiliknya (11). Adapun ukuran jantung normal tikus putih berdasarkan penelitian yang pernah dilakukan sebesar 2,98 $\pm 0,15 \mathrm{mg} / \mathrm{g}$ $\mathrm{BB}$, dengan $\mathrm{p}<0,05$ yang diukur dari 16 ekor tikus putih dengan berat badan 180-220 gram (12). Jantung bukan organ sasaran biasa, sehingga organ ini dapat dirusak oleh berbagai jenis zat atau senyawa. Zat itu bekerja secara langsung pada otot jantung atau secara tak langsung melalui susunan saraf atau pembuluh darah (13). 
Paru-paru merupakan organ tubuh dengan struktur yang elastis. Organ ini berperan penting dalam sistem pernapasan. Fungsi utama paru-paru yaitu untuk pertukaran gas antara darah dan atmosfer. Pertukaran gas tersebut bertujuan untuk menyediakan oksigen bagi jaringan dan mengeluarkan karbon dioksida (14). Karena paru-paru berhubungan langsung dengan udara luar, maka organ ini mempunyai kemungkinan terpapar zat berbahaya dan memiliki kerentanan terserang penyakit lebih tinggi dibandingkan organ lain yang tertutup (15).

Jantung dan paru-paru merupakan dua organ yang memiliki keterkaitan yang cukup signifikan. Jika salah satu mengalami masalah atau gangguan, maka akan berdampak pada organ lainnya. Pada organ jantung, salah satu tanda dari gangguan organ ini adalah adanya perubahan ukuran jantung. Secara umum apabila terjadi perubahan ukuran jantung, maka hampir bisa dipastikan adanya indikasi terdapat kelainan jantung.

Perubahan bobot organ seperti jantung dan paru ini sering dikaitkan dengan efek pengobatan atau pemberian suatu senyawa. STP (The Society of Toxicologic Pathology) menganggap bobot paru-paru merupakan standar dan titik akhir berharga dalam studi pernapasan. Sedangkan peningkatan bobot jantung mungkin merupakan satusatunya bukti hipertrofi miokard yang seringkali sulit dikenali baik secara makro maupun mikroskopis (16).

Berdasarkan uraian di atas, penelitian ini dilakukan untuk menguji pengaruh pemberian ekstrak etanol kayu secang (Caesalpinia sappan L.) secara subkronik terhadap bobot jantung dan paru tikus putih (Rattus norvegicus). Efek sampel dinilai berdasarkan pengukuran terhadap bobot jantung dan paru-paru tikus putih (Rattus norvegicus) yang telah dipaparkan ekstrak etanol kayu secang (Caesalpinia sappan L.) selama 90 hari.

\section{METODE PENELITIAN}

\section{Penyiapan dan Perlakuan Hewan Uji}

Proses adaptasi dilakukan terhadap hewan uji selama tujuh hari dengan pemberian pakan pellet dan penggantian sekam secara rutin 2 kali dalam seminggu. Hewan uji dibagi dalam 4 kelompok perlakuan yaitu kelompok 1 (kontrol sehat); kelompok 2 (suspensi NaCMC 1\% sebagai kontrol pembawa); kelompok 3 (ekstrak etanol kayu secang $400 \mathrm{mg} / \mathrm{kg}$ ); kelompok 4 (ekstrak etanol kayu secang $1000 \mathrm{mg} / \mathrm{kg}$ ).

\section{Penyiapan Suspensi NaCMC 1\% b/v}

NaCMC merupakan bahan yang berfungsi sebagai pembawa dalam membuat suspensi obat dengan cara pembuatan yaitu sebanyak 1 gram NaCMC dimasukkan sedikit demi sedikit ke dalam lumpang, lalu dicampurkan dengan air suling pada suhu $70^{\circ} \mathrm{C}$ dan digerus hingga terbentuk suspensi NaCMC. Suspensi kemudian dimasukkan ke dalam labu tentukur 100 $\mathrm{ml}$ dan dicukupkan hingga batas penanda.

\section{Penyiapan Sampel Penelitian}

\section{Pengambilan dan Pengolahan Sampel}

Sampel kayu secang (Caesalpinia sappan L.), diambil dari Pasar Daya, Kota Makassar, Provinsi Sulawesi Selatan. Sampel yang diperoleh disortasi dan dipisahkan dari pengotor, kemudian dicuci di bawah air mengalir, lalu diserut kemudian diserbukkan untuk memperbesar jumlah luas permukaan sampel dan disimpan dalam wadah kedap udara yang selanjutnya akan dilanjutkan dengan proses ekstraksi sampel.

\section{Proses Ekstraksi Sampel}

Proses ekstraksi sampel menggunakan metode maserasi dengan pelarut etanol 70\%. Sampel kayu secang yang telah diserbukkan ditimbang sebanyak 500 gram, kemudian dimasukkan ke dalam maserator. Pelarut etanol 70\% dimasukkan hingga semua sampel terbasahi dan volume pelarut mencapai 3 liter. Proses ekstraksi dilakukan selama 5 hari pada suhu ruang dan sekali-sekali diaduk, kemudian disaring menggunakan kain saring. Residu atau ampas kemudian diremaserasi menggunakan metode seperti maserasi sebelumnya dan diulang sebanyak tiga kali. Filtrat selanjutnya ditampung dan diuapkan menggunakan rotary evaporator, hingga diperoleh ekstrak kental. Kemudian ekstrak kental diangin-anginkan untuk memperoleh ekstrak kering (serbuk).

\section{Penyiapan Sediaan Uji dan Dosis Pemberian}

Ekstrak kayu secang dibuat suspensi dengan 2 variasi dosis yaitu $1000 \mathrm{mg} / \mathrm{kg}$ BB dan $400 \mathrm{mg} / \mathrm{kg}$ BB. Ekstrak ditimbang sesuai dengan variasi dosis yang digunakan kemudian disuspensikan dengan NaCMC $1 \%$ hingga $10 \mathrm{ml}$ ke dalam labu tentukur hingga diperoleh dosis yang diinginkan.

Perlakuan Hewan Uji

Hewan uji diberikan pemberian sesuai dengan kelompok perlakuan masing-masing secara oral dengan menggunakan kanula. Setelah 90 hari perlakuan, dilakukan penimbangan bobot badan, pembedahan, dan pengambilan organ jantung dan paru-paru dari hewan uji.

Pembedahan Hewan Uji

Hewan uji dibunuh dengan cara cervical dislocation (dislokasi leher), dengan menggunakan bantuan eter. Kemudian hewan uji diposisikan pada papan bedah menggunakan pins. Selanjutnya hewan uji dibedah mulai dari bagian perut menggunakan gunting bedah. Masing-masing organ kemudian diambil dan dipisahkan, lalu dibersihkan dari lemak yang masih menempel. Setelah dibersihkan, organ dicuci lagi dengan air suling dan $\mathrm{NaCl}$ fisiologis hingga bersih dari darah, lalu ditiriskan di atas kertas saring.

\section{Analisis Bobot Jantung dan Paru-Paru}

Setelah pembedahan dilakukan terhadap hewan uji, kemudian diambil organ jantung dan paru-paru. Organ yang telah diambil kemudian ditimbang pada timbangan analitik untuk melihat bobot jantung dan paru-paru hewan uji setelah perlakuan sesuai dengan kelompok perlakuan masingmasing. Bobot organ yang diamati adalah bobot absolut dan bobot rasio (perbandingan antara bobot organ dan bobot badan).

Pengumpulan Data dan Evaluasi Bobot Jantung dan Paru-Paru

Data hasil pengukuran bobot jantung dan paru-paru dikumpulkan dan dilakukan analisis data untuk mendapatkan hasil dari penelitian yang dilakukan.

\section{Analisis Data, Pembahasan, dan Kesimpulan}

Data hasil pengukuran bobot jantung dan paru-paru yang diperoleh selanjutnya diolah dengan pendekatan statistik yang sesuai. Setelah dilakukan analisis data, dilakukan pembahasan berdasarkan hasil yang diperoleh dari olah statistik. Penarikan kesimpulan dilakukan berdasarkan hasil yang telah dibahas.

\section{HASIL DAN PEMBAHASAN}

Penelitian ini menggunakan hewan uji tikus putih jantan (Rattus norvegicus) dengan bobot badan antara 150-200 gram. Sebelum diberi perlakuan, hewan coba terlebih dahulu diaklimatisasi selama 1 minggu, agar hewan coba dapat menyesuaikan diri dengan lingkungan dan kandang yang ditempati. 
Pada penelitian ini digunakan 28 ekor tikus putih (Rattus norvegicus) yang dibagi menjadi empat kelompok, yaitu kelompok kontrol sehat yang tidak diberi perlakuan apapun, kontrol negatif yang diberikan NaCMC 1\%, kelompok uji ekstrak etanol kayu secang dosis $400 \mathrm{mg} / \mathrm{kg} \mathrm{BB}$, dan kelompok uji ekstrak etanol kayu secang dosis $1000 \mathrm{mg} / \mathrm{kg}$ BB. Masing-masing kelompok dibagi menjadi 5 replikasi.

Kelompok uji yang digunakan pada penelitian ini adalah kelompok uji ekstrak etanol kayu secang dosis $400 \mathrm{mg} / \mathrm{kg} \mathrm{BB}$ dan dosis $1000 \mathrm{mg} / \mathrm{kg}$ BB. Penggunaan dosis pada kelompok ekstrak etanol kayu secang dosis $400 \mathrm{mg} / \mathrm{kg}$ BB didasarkan pada studi literatur yang telah dilakukan, dimana dosis 400 $\mathrm{mg} / \mathrm{kg}$ BB merupakan dosis yang paling banyak memberikan efek farmakologis. Sedangkan untuk dosis $1000 \mathrm{mg} / \mathrm{kg}$ BB digunakan berlandaskan dasar ketika sampel diberikan secara subkronik, kemudian tidak ada efek yang muncul, maka senyawa ini dikatakan aman. Pernyataan ini diperkuat pada Peraturan BPOM, dikatakan bahwa jika pada dosis 1000 $\mathrm{mg} / \mathrm{kg}$ BB tidak dihasilkan efek toksik, maka dosis tidak perlu dinaikkan lagi (17).

Setelah penelitian dilakukan, maka diperoleh hasil berupa data bobot organ jantung dan paru-paru sesuai dengan kelompok perlakuan masing-masing, yang ditimbang dengan menggunakan timbangan analitik. Data yang diperoleh dianalisis secara statistik menggunakan metode Analysis of Variance (ANOVA).

Hasil pengamatan bobot jantung dan paru-paru pada tikus putih jantan akibat pemberian ekstrak etanol kayu secang dibandingkan dengan kontrol sehat dan kontrol negatif disajikan pada Tabel 1.

Tabel 1. Hasil pengukuran rata-rata bobot jantung dan paru-paru tikus putih jantan

\begin{tabular}{lcc}
\hline \multirow{2}{*}{ Kelompok Perlakuan } & \multicolumn{2}{c}{ Bobot Organ (gram) } \\
\cline { 2 - 3 } & Jantung & Paru-Paru \\
\hline Kontrol Sehat & 0,68 & 1,66 \\
Kontrol Negatif (NaCMC) & 0,70 & 1,66 \\
Ekstrak Etanol Kayu Secang & 0,66 & 1,52 \\
$400 \mathrm{mg} / \mathrm{kg} \mathrm{BB}$ & 0,62 & 1,68 \\
$\begin{array}{l}\text { Ekstrak Etanol Kayu Secang } \\
1000 \mathrm{mg} / \mathrm{kg} \mathrm{BB}\end{array}$ & \\
\hline
\end{tabular}

Berdasarkan hasil penelitian, pengamatan, dan pengolahan data, dilihat dari nilai rata-rata tiap kelompok perlakuan, terlihat bahwa pada kelompok hewan uji yang diberi ekstrak etanol kayu secang $400 \mathrm{mg} / \mathrm{kg}$ BB dan $1000 \mathrm{mg} / \mathrm{kg} \mathrm{BB}$, serta kontrol sehat dan kontrol negatif tidak menunjukkan adanya perbedaan yang nyata antar perlakuan terhadap bobot jantung dan paru-paru tikus putih jantan.

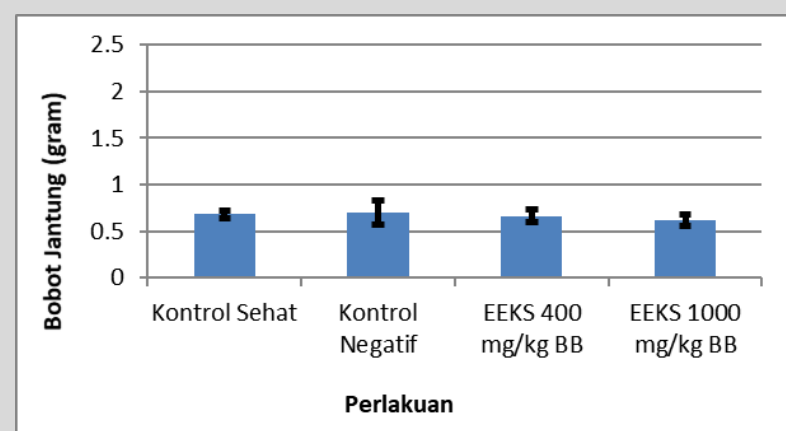

Gambar 1. Diagram bobot jantung tikus putih setelah pemberian ekstrak etanol kayu secang selama 90 hari

Berdasarkan diagram bobot jantung dan paru-paru tikus putih pada Gambar 1 dan Gambar 2, disertai dengan nilai standar deviasinya, dapat dilihat bahwa kelompok kontrol sehat yang tidak menerima perlakuan apapun menunjukkan hasil yang tidak bermakna dengan kelompok kontrol negatif yang diberikan perlakuan NaCMC 1\%, kelompok kayu secang dosis $400 \mathrm{mg} / \mathrm{kg} \mathrm{BB}$, dan kelompok kayu secang dosis 1000 $\mathrm{mg} / \mathrm{kg}$ BB. Perbedaan yang tidak bermakna menunjukkan bahwa pemberian ekstrak etanol kayu secang secara subkronik selama 90 hari tidak menyebabkan adanya gangguan pada bobot organ jantung dan paru-paru tikus putih jantan (Rattus norvegicus) berdasarkan peningkatan maupun penurunan bobot organ jantung dan paru-paru.

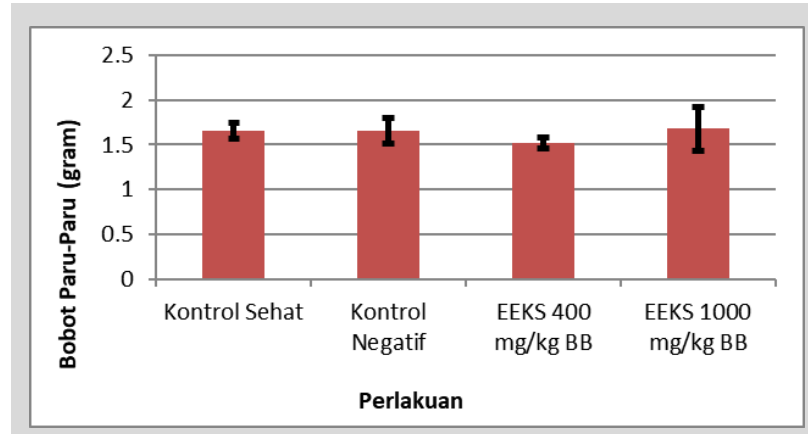

Gambar 2. Diagram bobot paru-paru tikus putih setelah pemberian ekstrak etanol kayu secang selama 90 hari

Data dianalisis secara statistik menggunakan aplikasi SPSS, untuk melihat homogenitas dan normalitas dari data yang diperoleh, serta melihat ada tidaknya pengaruh yang signifikan atau perbedaan nyata dari rata-rata bobot organ jantung dan paru-paru tikus putih (Rattus norvegicus) tiap kelompok perlakuan.

Pada tabel uji normalitas untuk data bobot jantung dan paruparu tikus putih, diketahui data bobot jantung dan paru-paru tikus untuk semua kelompok perlakuan berdistribusi normal. Sedangkan pada tabel uji homogenitas Levene, diketahui bahwa varians data bobot jantung dan paru-paru tikus pada semua kelompok perlakuan adalah sama atau homogen.

Berdasarkan data normalitas dan homogenitas dari bobot organ jantung dan paru-paru tikus putih jantan (Rattus norvegicus) yang ada pada tiap tabel uji, maka data selanjutnya diolah dengan analisis One Way Anova, dengan tujuan untuk membandingkan nilai rata-rata bobot organ yang terdapat pada tiap kelompok perlakuan, yang nantinya akan menentukan ada tidaknya perbedaan yang signifikan dari keempat kelompok perlakuan.

\begin{tabular}{lcc}
\multicolumn{3}{l}{$\begin{array}{l}\text { Tabel 2. Hasil pengukuran rata-rata bobot relatif organ jantung dan } \\
\text { paru-paru tikus putih jantan }\end{array}$} \\
\hline \multicolumn{1}{c}{ Kelompok Perlakuan } & \multicolumn{2}{c}{ Bobot Relatif Organ (\%) } \\
\cline { 2 - 3 } & Jantung & Paru-Paru \\
\hline Kontrol Sehat & 0,30 & 0,72 \\
Kontrol Negatif (NaCMC) & 0,37 & 0,88 \\
$\begin{array}{l}\text { Ekstrak Etanol Kayu Secang } \\
400 \text { mg/kg BB }\end{array}$ & 0,29 & 0,67 \\
$\begin{array}{l}\text { Ekstrak Etanol Kayu Secang } \\
1000 \text { mg/kg BB }\end{array}$ & 0,31 & 0,86 \\
\hline
\end{tabular}

Pada tabel ANOVA, diketahui nilai signifikansi dari data bobot jantung tikus untuk tiap kelompok perlakuan sebesar 0,911. Sedangkan nilai signifikansi dari bobot paru-paru tikus sebesar 0,871. Berdasarkan hasil di atas, diketahui bahwa nilai signifikansi dari bobot jantung dan paru-paru tikus putih jantan hasilnya lebih besar dari 0,05. Dari nilai signifikansi tersebut, maka dapat dikatakan bahwa data dari semua kelompok perlakuan tersebut tidak menunjukkan perbedaan yang signifikan terhadap kelompok perlakuan yang lain. 
Selain itu, dalam penelitian ini juga dihitung bobot relatif dari tiap organ jantung dan paru-paru tikus untuk semua kelompok perlakuan. Bobot relatif merupakan rasio atau perbandingan antara bobot organ tikus dengan bobot badan dari tikus tersebut. Hasil perhitungan bobot relatif organ jantung dan paru-paru tikus putih jantan (Rattus norvegicus) dapat dilihat pada Tabel 2.

Menurut Schoeffner dkk (1999), bobot relatif organ jantung tikus putih sebesar 0,26-0,58. Sedangkan bobot relatif organ paru-paru tikus putih sebesar 0,32 - 0,86. Berdasarkan tabel 2, dapat dilihat bahwa nilai rata-rata bobot relatif pada kelompok hewan uji yang diberi ekstrak etanol kayu secang $400 \mathrm{mg} / \mathrm{kg} \mathrm{BB}$ dan $1000 \mathrm{mg} / \mathrm{kg} \mathrm{BB}$, serta kontrol sehat dan kontrol negatif sesuai dengan bobot relatif organ jantung dan paru-paru tikus putih yang ditunjukkan oleh Schoeffner dkk. Hal ini menjelaskan bahwa secara umum, perubahan bobot organ jantung dan paru-paru tikus putih jantan (Rattus norvegicus) juga dipengaruhi oleh perubahan bobot badan yang dialami oleh tikus tersebut.

\section{KESIMPULAN}

Berdasarkan penelitian yang dilakukan mengenai pengaruh pemberian ekstrak etanol kayu secang (Caesalpinia sappan L.) secara subkronik terhadap bobot jantung dan paru-paru tikus putih jantan (Rattus norvegicus), diperoleh hasil bahwa pemberian ekstrak etanol kayu secang (Caesalpinia sappan L.) dosis $400 \mathrm{mg} / \mathrm{kg} \mathrm{BB}$ dan dosis $1000 \mathrm{mg} / \mathrm{kg} \mathrm{BB}$ tidak memberikan indikasi adanya efek toksik pada organ jantung dan paru-paru.

\section{DAFTAR PUSTAKA}

1. Jumiarni WO, Komalasari O. Eksplorasi Jenis dan Pemanfaatan Tumbuhan Obat pada Masyarakat Suku Muna di Pemukiman Kota Wuna. Traditional Medicine Journal. 2017;22(1):45-46.
2. Witjoro A, Sulisetijono, Setiowati FK. Pemanfaatan Tanaman Obat di Desa Kayukebek, Kecamatan Tutur, Kabupaten Pasuruan. Jurnal Natural B. 2016;3(4):304.

3. World Health Organization (WHO). Development of Traditional Medicine in The South-East Asia Region. Report of a Regional Consultative Meeting Pyongyang, DPR Korea; 2005.

4. Sari R, Suhartati. Secang (Caesalpinia sappan L.) Tumbuhan Herbal Kaya Antioksidan. Info Teknis EBONI. 2016;13(1):57-67.

5. Sugiarto IP, Nurulita NA, Hartanti D. Efek Antiangiogenesis Fraksi VI dan VII Ekstrak Metanolik Kayu Secang (Caesalpinia sappan L.). Journal of Pharmacy. 2010;7(2):90-105. DOI: 10.30595/pji.v7i1.560

6. Rahman S, Kosman R, Wijaya II. Uji Efek Hipolidemik Ekstrak Etanol Kayu Secang (Caesalpinia sappan L.) terhadap Tikus Wistar (Rattus norvegicus) Jantan. Jurnal As-Syifaa. 2015;7(2):103-113.

7. Pertamawati, Sriningsih, Fahrudin F, Efendi J. Konsumsi Ekstrak Secang (Caesalpinia sappan L.) terhadap Volume Urin Tikus Putih Jantan Galur (Rattus norvegicus). Jurnal Jamu Indonesia. 2017;2(3):121-126.

8. Utari FD, Sumirat, Djaeni M. Produksi Antioksidan dari Ekstrak Kayu Secang (Caesalpinia sappan L.) menggunakan Pengering Berkelembaban Rendah. Jurnal Aplikasi Teknologi Pangan. 2017;6(3):1-4.

9. Rusdi UD, Widowati W, Marlina ET. Efek Ekstrak Kayu Secang, Vitamin E dan Vitamin C terhadap Status Antioksidan Total (SAT) pada Mencit yang Terpapar Aflatoksin. Jurnal Media Kedokteran Hewan. 2005;21(2):6668.

10. Tortora GJ, Derrickson B. Principles of Anatomy and Physiology 13th Edition. United States of America: John Wiley \& Sons, Inc; 2012.

11. Ulfah A. Gejala Awal dan Deteksi Dini Penyakit Jantung Koroner. Artikel Ilmiah Pd-PERSI. 2000.

12. Krames BB, Liere EJV. The Heart Weight and Ventricular Weights of Normal Adult Albino Rats. The Anatomical Record. 1966;156(4):461464.

13. Frank. Toksikologi Dasar: Asas, Organ Sasaran, dan Penilaian Resiko. Jakarta: UI Press; 1995.

14. West JB. Respiratory Physiology The Essentials 7th Edition. Pennysylvania: Lippincott Williams and Wilkins; 2004.

15. Novitasari, Made Oka. Analisis Histopatologi Organ Paru-Paru Mencit (Mus musculus) yang Diberi Pretreatment Untuk Penyiapan Penelitian Biomedis. Skripsi tidak diterbitkan. Bogor: Fakultas Kedokteran Hewan IPB; 2017.

16. Sellers RS, Daniel M, Bindhu M, Nigel R, Julie KJ, Barry LY, Rick P, Ken S Society of Toxicologic Pathology Position Paper: Organ Weight Recommendations for Toxicology Studies. Toxicologic Pathology. 2007;35(5):751-755.

17. BPOM. Peraturan Kepala BPOM Nomor 7 Tahun 2014 tentang Pedoman Uji Toksisitas Nonklinik Secara In Vivo. 2014. 